\title{
MONITORINGUL FITOSANITAR ASUPRA NEMATOFAUNEI PARAZITARE ÎN AGROCENOZE DE TIP INTENSIV LA MĂR ȘI PIERSIC
}

\author{
lurcu-Străistaru Elena, Toderaș lon, Bivol Alexei, \\ Rusu Ștefan, Sasanelli Nicola ${ }^{1}$ \\ Institutul de Zoologie al MECC, or. Chișinău, Republica Moldova \\ ${ }^{1}$ Institutul de Protecție a Plantelor (IPP), secția Nematologie, sectorul Bari, Italia \\ E-mail: iurcuelena@mail.ru
}

https://doi.org/10.53937/9789975315975.45

Managementul durabil în crearea și valorificarea agrocenozelor de măr și piersic de tip intensiv impun diverse obiective agrobiologice cu valori incontestabile pentru asigurarea productivității înalte în diverse tipuri de livezi productive și zone agroecologice ale Republicii Moldova. Un dezavantaj esențial în explorarea plantelor pomicole în sistem de monocultură, sunt factorii de mediu favorabili, care contribuie și la formarea complexelor fitoparazitare infecțioase și vectoriale ce determină afecțiuni grave provocate recoltei de fructe și pomilor, cu diminuearea potenţialului productiv în livezi. În acest context, aceste contribuții sunt determinate de gama largă de organisme nocive ce parazitează pe aceste culturi în perioada activă de vegetaţie, inclisiv și agenții fitoparazitari helmintologici cu specializare vectorială ai virusurilor fitopatogene. Aceste complexe responsabile de declanșarea fitohelmintozelor și virozelor merită o deosebită atenție și cercetare particulară în relevarea impactului fitoparazitar, gradului de infestare fitohelmintotică și virotică.

Monitoringul fitosanitar realizat asupra complexelor de fitonematode parazite au o semnificaţie majoră teoretică și aplicativă, deoarece în timpul apropiat se preconizează aplicarea noilor metode de bioindicatori în depistarea stării fotosanitare a sectoarelor agricole, în noile sisteme de cultivare a culturilor pomicole. Reieșind din actualitatea temei de cercetare scopul și obiectivele reflectă: Realizarea monitoringului și structurii complexelor de fitonematode parazite la culturile de măr și piersic pentru relevarea impactului fitoparazitar și vectorial 
din diverse agrocenoze de măr și piersic și zone ale Republicii Moldova pentru a elucida impactul fitoparazitar, evidența structurii complexelor de fitonematode, frecvenței unităților taxonomice, efectivului numeric conform legităților de adaptare și funcționare trofică în dependență de zonă, sol, condiții de mediu, vârsta pomilor și întreținerea agrofondului tehnologic.

S-au investigat agrocenozele pomicole de măr și piersiv productive de tip intesiv din raioane administrative pe suprafețe de peste 800 hectare din zona Nord-raioanele Briceni și Soroca, zona Centru-raioanele Criuleni, laloveni, zona Sud - Est raioanele - Căușeni, Ștefan -Vodă, unde s-au întreprins sondaje de evidență fitosanitară cu prelevarea probelor de sol din rizosfera pomilor de măr și piersic în profunzimea $30-55 \mathrm{~cm}$ și segmente de rădăcini minuscule superficiale. Studiul materialului nematofaunistic s-a cercetat în Laboratorul de Parazitologie și Helmintologie al Institutului de Zoologie cu analiza a peste a 100 probe de sol și plante și utilizarea metodei modificate Baerman funnel prin flotație-decantare și fixare în $4 \%$ formalină, la temperatura $60^{\circ} \mathrm{C}$. Pentru stabilirea efectivului numeric și dentificarea taxonomică la nivel de gen și specie, specializare trofică și alte particularități biologice s-a utilizat microscopul binocular.

În rezultatul analizelor de probe în laborator s-a constatat abundența efectivului numeric în valori medii de 420-670 ex/100 g sol în plantaţii de măr a zonei Nord comparativ cu zonele Centru și Sud-Est, unde amplituda valorilor este mai mare (460-1300 ex/100 g sol) din cauza variațiilor de temperatură și umiditate în prima perioadă de vegetaţie activă, (aprilie-iunie). În plantaţiile de piersic efectivul numeric a remercat valori medii de 220-620 ex/100 g sol în plantaţiile zonei Centru, iar în zona Sud-Est densitatea valorilor fiind mai mare (360-700 ex/100 g sol), reeșind din influenţa factorilor de mediu, suprafeţe extinse și nerespectarea asolamentului Aceste valori comparative sunt caracteristice condițiilor de mediu pentru anul 2016, caracterizată în alternanţă cu exces de umeditate, (aprilie-iunue), temperatură și secetă îndelungată (iulie-septembrie). Rezultatele analizelor din 2017, remarcă frecvența efectivului numeric la 
măr în valori medii de $370-580$ ex/100 g sol depistate în sectoarele zonei Nord, iar în livezile zonei Centru și Sud-Est, s-au remarcat valori medii de 220-4200 ex/100 g sol, cu 20-28\% mai reduse comparativ cu sectoarele zonei Nord, din motive de exces de umiditate în perioade îndelungate și temperaturi avansate și plantaţii repetate de măr pe același teren, (cele vechi pe cele de tip nou). În rezultatul constatării diversității taxonomice a fitonematodelor depistate pe perioada anilor 2016-20117, s-a determinat un număr de 32 specii de fitonematode parazite de specializare trofică variată incluse în 3 grupe, cu predominanța speciilor fitoparazite (18 specii ectoparazitare), care afectează gav zona perilor absorbanți cu efect specific patogen urmate de 14 specii cu adaptare endo-semi-endo parazitară. Au fost identificate cele mai frecvente specii în comunități stabile, practic în toate sectoarele investigate din genurile: Pratylenchus, Rotylenchus, Ditylenchus, Criconemoides etc. s-au depistat și evidențiat speciile vectori de nepo-virusuri și tabro-virusuri cum sunt: Xiphinema index, X. Riversi, X.americanum, X. brevicole, X. vuitennezi, Longidorus elongatus, drept dovadă au fost efectuată evidența gradului de afecțiune virotică în valori medii de 5-18\%, practic în toate agrocenozele de măr investigate cum sunt simptome de uscare prematură a ramurilor, scurtnodarea lăstarilor, cloroze și gofrări virotice cu urmări patologice grave ireversibile pomilor de măr și piersic. Aceste investigații nematofaunistice prezintă o semnificație majoră teoretico-aplicativă, ca o prognoză bioindicatoare în evaluarea controlului biologic fitoparazitar în livezile de măr și piersic în ajustarea unor metode de reglare a impactului fitoparazitar și afectivului numeric.

Investigațiile au fost realizate în cadrul proiectului 15.817.02.12F, finanțat de Consilul Supărem pentru Știință și Dezvoltare Tehnologică al Academiei de Stiințe a Moldovei și a proiectului STCU-6233 din cadrul Programului direcţiei strategice Iniţiative Comune de Cercetare - Dezvoltare, cu cifrul 17.80013.5107.12/6233. 